\title{
Applying the Cultural-Conceptual Translation Model in the Commercial World of Tourism Promotion
}

\author{
M Zain Sulaiman \\ Faculty of Social Sciences and Humanities \\ Universiti Kebangsaan Malaysia \\ Bangi, Selangor, Malaysia \\ zain@ukm.edu.my
}

\begin{abstract}
Following criticism against translated tourism promotional materials in the last few decades, scholars in the field of Translation Studies have attempted to address the issues involved and propose solutions. This study, which is an extension of the author's earlier work on the practices and misconceptions of the commissioners of cross-cultural tourism promotional materials (TPMs), carries out a practical translation project in the commercial world of tourism promotion. The purpose of the project is to test the viability and effectiveness of a translation model called the cultural-conceptual translation (CCT) model. The application of the CCT model in the translation project provided the project commissioners with a different perspective on the concept of translation. Both the approach and the outcome were very well received by the commissioners, who recognized that an ideal scenario would be one in which they could find an accomplished translator who can implement the necessary culturally-driven changes. The project also highlighted the importance of cross-cultural input in the translation process, which could be commissioner-initiated or translator-initiated. It also demonstrated that a cost-effective and efficient way of translating TPMs for different markets is to design source texts based on cultural similarities.
\end{abstract}

Keywords-translation of tourism promotional materials; translation commissioners; cultural-conceptual translation; cultural translation; tourism promotion

\section{INTRODUCTION}

The author's earlier study on the practices of the commissioners of cross-cultural tourism promotional materials (TPMs) of a state tourism authority (Sulaiman, 2016a) found a number of interesting results, including the existence of a gap between what the commissioners deem to be the ideal scenario for the production of cross-cultural TPMs and the actual practices of the commissioners. The gap can be attributed to a number of misconceptions regarding the nature of translation and the role of translators. The main misconception held by the commissioners is that translation is a purely linguistic, mechanical process, not a creative or a cultural one, and as a consequence, they assumed that the role of translators is limited to performing purely linguistic rendering of texts (direct translations) from one language to another. The commissioners interviewed did not see translators as bi- cultural experts or cultural mediators who are actively involved in shaping target texts. As a result of these misconceptions, it was the practice of the commissioners not to engage translators but rather bi-lingual copywriters to 'rewrite' their TPMs in the target languages. Finally, the study argues that addressing these misconceptions has the potential to not only improve the effectiveness and efficiency of crosscultural tourism promotion but more importantly uplift the image of the translation profession as a whole.

This paper builds on the author's earlier research by carrying out an actual translation project in a commercialworld setting with the same commissioners. The purpose of this study to test the viability and effectiveness of the culturalconceptual translation (CCT) model (Sulaiman \& Wilson, 2018) which was developed specifically for the translation of tourism promotional materials. Contrary to the views (misconceptions) of the commissioners, the CCT model regards translation as a cultural process in which source texts are rewritten in the target language based on the sociocultural, ideological and literary constraints which lie behind the production of the target text. Accordingly, translators are not viewed as mere transferor of words and sentences between languages but as mediators of cultures and cross-cultural experts. Therefore, under the CCT model, translators are not only required to master the nuances of the target language at a native level but also the nuances of the target audience and culture. More specifically, translators need to know how tourism is conceptualised in the culture of the target audiences and how these new audiences can be converted to tourists. The application of the CCT model in this project seeks to provide the commissioners with a different perspective of the concept of translation and role of translator and to examine the practicality of the CCT model in a commercial world setting. It also seeks to demonstrate some of the challenges and sustainable solutions in TPM translation. Lastly, I interrogate how the findings from this study might be used to help inform and shape best practices in TPM translation.

\section{The Cultural-Conceptual Translation Model}

The past few decades have witnessed the emergence of the language of tourism promotions as a field of research among 
linguists. This area of specialisation has also become an area of interest among scholars of Translation Studies particularly with the increasing amount of criticism made against the quality of translation in the tourism industry (e.g., Federici, 2007, p. 111; Katan, 2012, p. 89; Parks, 2014, pp. 1-5; Pierini, 2007, p. 90; Sulaiman, 2016a, pp. 54-65; Sumberg, 2004, pp. 329-350; Valdeón, 2009, pp. 43-45). Although culture, or rather cultural differences, have been identified as the main reason behind the failure of translations in the tourism industry, no straightforward solution to dealing with the problem has been found. In an attempt to address this shortcoming, Sulaiman and Wilson (2018) proposed a Cultural-Conceptual Translation model, which is based on the well-developed functional approach to translation and subscribes to the view that a culturally oriented functional approach is central to advertising translation. The CCT model focuses on two interrelated macro-level factors that are crucial to the dynamics of TPM translation: (a) translation purpose, which in TPM translation is directly linked to the notion of destination image (which is drawn from Tourism Studies) and (b) cultural conceptualisation (which is drawn from Cultural Linguistics), the means by which the TPM purpose is achieved. The CCT model asserts that the effectiveness of TPM translation relies on the (re)construction of 'favourable' destination images in the mind of the readers with the hope that these will convert them into tourists. Destination images here refers to the mental images, perceptions, impressions, ideas, expectations, and feelings held by people towards a place (Rajesh, 2013, p. 68). These images are constructed using 'favourable' destination attributes and qualities, also known as 'pull-factors' which play the role of attracting potential consumers. Hence, the creation of 'favourable' destinations images becomes an overriding conditions that justifies the translations methods and strategies deemed necessary.

The model stresses that just as how beauty is conceptualised differently across cultures, so is the case with destination images. What constitutes an appealing or favourable destination image may very well vary from one culture to another as shown by research in Tourism Studies (Kozak, Bigne, Gonzalez, \& Andreu, 2003, p. 256; MacKay \& Fesenmaier, 2000, p. 417). Destination images must be designed in a way that matches tourist needs and wants: these are the culturally-driven 'push-factors' that complement the 'pull-factors' and are an essential component of any marketing campaign. This is where cultural conceptualisation, denoting culturally-generated ways of conceptualising experience, comes to the fore. As Sharifian notes, 'at the cultural level of cognition, meanings and conceptualisations appear to arise from the interaction between the members of a cultural group' (2011, p. 24). So, for example, Anglo-Australians might conceptualise the dog as 'man's best friend', while in the Malay culture the dog is generally conceptualised as despicable, weak and evil (Imran Ho-Abdullah, 2011, p. 138). While cultural conceptualisations are not equally imprinted in the mind of every individual member of a group, they are more or less evenly shared between the members (Sharifian, 2013, p. 91). These shared conceptualisations are the result of underlying common value dimensions such as individualism- collectivism, power distance, uncertainty avoidance and religious beliefs (MacKay \& Fesenmaier, 2000, p. 417).

The CCT model requires the translator to be highly interculturally competent. Translators need to know how tourism is conceptualised in the culture of the target audiences and how these new audiences can be converted to tourists by using effective destination images created through the blending of language and culture. The CCT model also requires two conditions to be met: (a) sufficient background knowledge on the tourist destination, product or experience being promoted, (b) effective negotiation with the commissioner of the translation.

\section{The TRANSLATION PROJECT}

The translation project was carried out with the commissioner-translator interaction being a key feature. The commissioner for the project was an Australian tourism authority (hereafter 'Tourism Authority') responsible for promoting and supporting the development of tourist destinations within the borders of one of Australia's states. The main function of the Tourism Authority is to market the state as a tourist destination for domestic and international travellers and to work in partnership with the local tourism industry. As part of its function, the organisation creates original advertisements and TPMs including brochures, leaflets, posters, flyers, postcards and websites. To cater for an international audience of various nationalities and cultural backgrounds, the TPMs have a number of language and market variants in which translation practices have played a key role in their creation. Representing the Tourism Authority in the project were two of its marketing managers, both of whom are university graduates with degrees in the field of international marketing and tourism, in their mid-thirties and with 6-9 years of experience in the field of tourism marketing and promotion. I am grateful for the opportunity given by the Tourism Authority and the views and insights provided by the two managers who commissioned the translation project (hereafter 'Commissioners').

The text selected for the project was the Tourism Authority's English-Arabic bilingual e-brochure, the quality of which was noticeably higher than that commonly observed in the marketplace, making the process of its creation a topic of research interest. For the purpose of the project, the English text of the brochure was translated into Malay to produce a bilingual English-Malay brochure for the Malaysian market. What is interesting about the English source text is that its original function was primarily to be translated into Arabic to lure Arabic-speakers of the Middle Eastern region, particularly the Gulf Cooperation Council (GCC) market segment (Saudi Arabia, United Arab Emirates, Kuwait, Qatar, Bahrain, and Oman), and secondarily to lure English-speaking expatriates residing in the same region. In other words, the content of the English source text was originally tailor-made with the GCC segment in mind. The motivational content included strategic themes and appeals which suit that segment (e.g., familial and less adventure-driven). Images were also carefully selected to meet the requirements of the target market segment. For example, images of women sunbathing and exposing too much 
skin were avoided. In fact, some of the images depicted what seem to be female Muslim tourists wearing headscarves. The informational content of the brochure was also tailored for the market by providing relevant information on such topics as halal restaurants, mosques, accommodation, public transport and tour operators. Based on the CCT model, the English source text was translated into Malay with the purpose of (re)constructing a favourable destination image in the mind of the Malay readers based on their cultural conceptualisation.

\section{FINDINGS AND DISCUSSIONS}

The brief for the translation project was negotiated and discussed with the Commissioners, who clearly instructed me not to translate the source text directly but to create a target text that will function effectively in the target culture. The instructions also required the omission of all references to wines and wineries that exists in the source text. I also discussed with the Commissioners the types of changes that could be implemented at my discretion and those which needed to be negotiated and approved by them prior to implementing these in the translated product. The Commissioners emphasised that I was at liberty to implement minor changes and modifications which did not affect the core content or overall meaning of the source text. Although the distinction between what is regarded as a 'minor change' and what is not, is not a simple one, the Commissioners did point out that changes which would definitely require their decision are those which involve 'excluding or including certain [tourism] products or certain [tourist] experiences'. The latter decision would rely on discussions and negotiations between the translators and Commissioners. On the other hand, changes which were regarded as minor by the Commissioners included changing a textual structure, rephrasing a sentence, opting for different words, and making small changes to the description of a tourism product or experience to render it more appealing to the target market.

A translation-oriented analysis of the English source text revealed that the features of the brochure were already consistent with many of the cultural values of the Malay market. Although the content of the source text was designed primarily for an Arab-Gulf audience, the fact that the value systems of the Arab-Gulf culture and the Malay culture have a lot in common, had a significant impact on the entire process of translation. The Arab-Gulf culture bears resemblance to the Malay culture in various cultural dimensions. Like the Malay culture, the Arab-Gulf culture is high in collectivism, uncertainty avoidance, power distance and restraint (Hofstede, Hofstede, \& Minkov, 2010). Both cultures also share a common religious framework, that is, Islam. In terms of communication style, both are categorised as high context communication cultures (Hall, 1976, 1984). Not only does the Arab-Gulf society share common cultural values with the Malays, they are also in the same tourism phase as the Malays: the sightseeing phase. With regard to climate, tourists from both cultures also show a similar interest in escaping the sun and searching for cooler environments and climate features which do not exist in their home country such as snow.
Due to the similarities between both cultures, much of the culturally-predicated content and many of the themes used in the source text are as appealing to Malay tourists as they are to Arab tourists. This meant that many of the themes were 'translation-friendly' or even 'translation-ready' and could be reproduced in the target text with minimal changes. As a result, the translation could be carried out more efficiently with less translational intervention, less negotiation and within a shorter period. Nevertheless, this did not mean that the translator is 'relieved' of his 'cross-cultural duties' as it is his or her responsibility as the bi-cultural expert to ensure that no cultural nuances are left unaddressed and to present the target text in a culturally effective style. Below I discuss some of the most significant cross-cultural inputs supplied by the Commissioners and further cross-cultural inputs that had to be added by the translator to render the content culturally functional for the Malay market. These cultural inputs could be loosely divided into two categories: content and style. At the content level, there were a number of cross-cultural inputs related to religion, family, tourist activities, and the beauty of nature. At the level of style, cross-cultural input was required in relation to the use of the imperative voice, poetic devices, and authentic Malay expressions.

One of the most significant cross-cultural aspects addressed by the Commissioners is dictates of Islamic gastronomy as evidenced in the brochure's dedicated informational section on halal eateries and the explicit instruction to omit all references made to wine and wineries. Nevertheless, insufficient attention had been paid to the provision of halal food. References made to what seem to be non-halal restaurants throughout the promotional section of the brochure raise questions with regard to the functionality of such content for a Muslim audience. Based on my interaction with the Commissioners, there seems to be some lack of understanding with regard to the concept of halal in Islamic gastronomy. They were quite surprised when I informed them that the gastronomy theme will not appeal to Malay tourists unless it is explicitly labelled as halal. This could be attributed to the common misconception that halal gastronomy is simply defined as the exclusion of pork and alcohol. This gastronomic issue was also left unaddressed in the Arabic translation, which in turn raises questions about the cross-cultural role of the Arabic copywriter as it seems that the Commissioners were not advised on this matter by the Arabic copywriter. In the case of my Malay translation, several strategies were used to overcome the problem. One of the strategies was to replace the gastronomy experience with another experience (omission with compensation) (Sulaiman, 2016b, p. 32). Since this particular translation strategy involves a change in a tourism product, it was negotiated with the Commissioners. One of the examples in which this strategy was employed is in the translation of 'Melbourne Food and Wine Festival' (Example 1). Based on the translation brief, which requires the omission of all references to wine, the phrase 'wine' only should be omitted, hence changing the name of the festival to 'Food Festival'. Although this strategy was adopted in the Arabic translation, it is quite problematic not only due to the fact that the concept of halal was not adequately addressed but also because it does not reflect the actual name of the festival. 
EXAMPLE 1

\begin{tabular}{|c|c|c|}
\hline Source Text (ST) & $\begin{array}{c}\text { Cultural-Conceptual } \\
\text { Translation (CCT) }\end{array}$ & $\begin{array}{c}\text { Back-Translation } \\
\text { (BT) }\end{array}$ \\
\hline $\begin{array}{l}\text { Major sporting events } \\
\text { such as the Australian } \\
\text { Formula One Grand } \\
\text { Prix and the Australian } \\
\text { Open Tennis } \\
\text { Championship, are } \\
\text { complemented by a } \\
\text { range of international } \\
\text { fashion, arts and cultural } \\
\text { events such as the } \\
\text { L'Oreal Melbourne } \\
\text { Fashion Festival and the } \\
\text { Melbourne Food and } \\
\text { Wine Festival. }\end{array}$ & $\begin{array}{l}\text { Di samping temasya } \\
\text { sukan terkemuka seperti } \\
\text { Australian Formula One } \\
\text { Grand Prix dan } \\
\text { Australian Open Tennis } \\
\text { Championship, pelbagai } \\
\text { acara fesyen, kesenian } \\
\text { dan kebudayaan } \\
\text { antarabangsa dianjurkan } \\
\text { termasuk L'Oreal } \\
\text { Melbourne Fashion } \\
\text { Festival dan Moomba } \\
\text { Festival. }\end{array}$ & $\begin{array}{l}\text { Apart from major } \\
\text { sporting events such as } \\
\text { the Australian Formula } \\
\text { One Grand Prix and the } \\
\text { Australian Open Tennis } \\
\text { Championship, various } \\
\text { international fashion, } \\
\text { arts and cultural events } \\
\text { are organised including } \\
\text { the L'Oreal Melbourne } \\
\text { Fashion Festival and } \\
\text { Moomba Festival. }\end{array}$ \\
\hline
\end{tabular}

I explained to the Commissioners the cross-cultural issues involved and proposed that 'Melbourne Food and Wine Festival' should be replaced with one of Melbourne's other cultural events. The Commissioners acknowledged, in principle, the need to make this change in the Malay translation. Although, my initial suggestion was to use the 'Melbourne International Film Festival' as a substitute, the Commissioners were of the view that it was not compelling enough. They argued that "there is no reason for travelling to a film festival when you can get it from your own country". Based on their strong knowledge of the tourism products and experiences, they suggested 'Moomba Festival' as a more viable substitute. Apart from the 'omission with compensation' strategy, the 'oral-visual consumption shift' strategy (Sulaiman, 2016b, p. 30) was also employed such as in Example 2.

\section{EXAMPLE 2}

\begin{tabular}{|c|c|c|}
\hline Source Text (ST) & $\begin{array}{c}\text { Cultural-Conceptual } \\
\text { Translation (CCT) }\end{array}$ & $\begin{array}{c}\text { Back-Translation } \\
\text { (BT) }\end{array}$ \\
\hline $\begin{array}{l}\text { Gourmet food producers } \\
\text { and celebrated } \\
\text { restaurants will keep } \\
\text { mum and dad busy }[\ldots]\end{array}$ & $\begin{array}{l}\text { Destinasi ini terkenal } \\
\text { dengan hasil segar } \\
\text { ladang-ladangnya dan } \\
\text { restoran-restoran } \\
\text { terkemuka. }\end{array}$ & $\begin{array}{l}\text { This destination is } \\
\text { famous for its fresh } \\
\text { farm produce and } \\
\text { leading restaurants. }\end{array}$ \\
\hline
\end{tabular}

In the above example, the gastronomic element 'celebrated restaurants' is preserved in the target text. However, its function is changed from being an object of oral consumption to an object of visual consumption.

Where the gastronomy theme was less significant and nonspecific, the omission strategy presented itself as a more viable option (Example 3). Example 2 and Example 3, as well as the subsequent examples of changes discussed in this section, are examples of minor changes which do not change the core content of the source text. They do not include or exclude a specific tourism product or experience, and therefore do not require the approval of the Commissioners. Nevertheless, for the purpose of this case study, examples of minor changes were also discussed with the Commissioners for their feedback.
EXAMPLE 3

\begin{tabular}{|c|c|c|}
\hline Source Text (ST) & $\begin{array}{c}\text { Cultural-Conceptual } \\
\text { Translation (CCT) }\end{array}$ & $\begin{array}{c}\text { Back-Translation } \\
\text { (BT) }\end{array}$ \\
\hline $\begin{array}{l}\text { Following a morning } \\
\text { ride through the } \\
\text { Dandenong Ranges on } \\
\text { Puffing Billy, enjoy an } \\
\text { afternoon of food, fun } \\
\text { and family activities on } \\
\text { the Mornington } \\
\text { Peninsula. }\end{array}$ & $\begin{array}{l}\text { Pada sebelah pagi } \\
\text { luangkan masa anda } \\
\text { untuk menaiki keretapi } \\
\text { Puffing Billy merentasi } \\
\text { banjaran Dandenong } \\
\text { Ranges. Kemudian } \\
\text { bergembira bersama } \\
\text { keluarga anda di sebelah } \\
\text { tengah hari di } \\
\text { semenanjung } \\
\text { Mornington Peninsula. }\end{array}$ & $\begin{array}{l}\text { In the morning spend } \\
\text { your time riding the } \\
\text { Puffing Billy train } \\
\text { across the Dandenong } \\
\text { Ranges. Then, enjoy } \\
\text { with your family in } \\
\text { the afternoon in } \\
\text { Mornington } \\
\text { Peninsula. }\end{array}$ \\
\hline
\end{tabular}

Emphasis in ST mine.

In addition to Islamic gastronomy, other cultural-religious content of the source text such as the dedicated section on mosques and visuals of Muslim women (presumably tourists) wearing Islamic attire are not only attractive features for Arab tourists but also for other tourists from the Muslim world such as the Malays. Moreover, the fact that the source text did not emphasise (non-Islamic) indulgence-oriented themes such as night life and partying, further enhanced the suitability of the source text content for the Malay culture which is high on restraint and adhere strictly to religious rules and cultural norms. However, there were some minor elements of indulgence and these were dealt with appropriately (Example 4):

EXAMPLE 4

\begin{tabular}{|c|c|c|}
\hline Source Text (ST) & $\begin{array}{c}\text { Cultural-Conceptual } \\
\text { Translation (CCT) }\end{array}$ & $\begin{array}{c}\text { Back-Translation } \\
\text { (BT) }\end{array}$ \\
\hline $\begin{array}{l}\text { Indulge in life's great } \\
\text { pleasures of food, fun } \\
\text { and nature on } \\
\text { Melbourne's doorstep }\end{array}$ & $\begin{array}{l}\text { Nikmati detik-detik indah } \\
\text { penuh kedamaian bersama } \\
\text { keluarga tersayang di } \\
\text { pinggir kota Melbourne. }\end{array}$ & $\begin{array}{l}\text { Enjoy beautiful } \\
\text { moments full of } \\
\text { tranquillity with your } \\
\text { beloved family on the } \\
\text { outskirts of Melbourne. }\end{array}$ \\
\hline
\end{tabular}

The above example is one of the main captions found in the brochure. In my Malay translation of the caption, the notion of indulgence was addressed by shifting the focus from 'indulgence' and 'pleasures' to 'enjoyment', 'beauty' and 'tranquillity'. Adding the optional phrase 'bersama keluarga tersayang' (with [your] beloved family), immediately after the word 'kedamaian', serves two functions. Firstly, it creates mood and music through the use of the poetic device of consonance (kedamaian [...] tersayang) in order to further enhance the persuasive effect of the caption, following the poetic device of alliteration used in the source text (food, fun). Second, it also reemphasises the familial dimension of the discourse, a key feature of the brochure which I shall now turn to.

In addition to the religious and restraint features of the source text, another salient feature of the source text is the profound use of collectivistic-familial themes. For example, keywords including 'family' (in its singular and plural forms) and 'kids' are used throughout the source text. In fact, the very first caption on the first page of the brochure promotes the destination as 'the ultimate adventure playground for families and romantics'. The theme is not only reflected verbally but 
also visually, with many images in the brochure depicting parents and children enjoying activities together. The familial dimension of the discourse is further enhanced by the notion of comfort and convenience. For example, the source text tries consistently to create an image of tourist attractions that can be visited easily and comfortably, through the use of the "ease of access' theme. Attractions located outside the capital city of the state are described as being within easy reach of tourists. This is reflected through the use of phrases such as 'within easy reach of the capital city', 'just 90 mins from Melbourne', 'only three hours from Melbourne', 'only one hour drive from Melbourne', 'on Melbourne's door step', and 'not far away'. This theme is used to pre-empt any sense of remoteness and difficulty which might be perceived by a sightseeing-oriented tourist who values comfort and convenience. In fact, the Commissioner's acknowledgment that some tourism regions were excluded from the source text for being 'too far' from the capital city for Arab tourists shows that the 'ease of access' theme is a deliberate strategy to attract this particular group of tourists.

Furthermore, the source text was designed to create an image of tourist activities and experiences which are nonintimidating, novice-friendly, family-friendly, relaxing and above all risk-free. Although this strategy was originally adopted to meet the needs of Arab tourists, it happens to be also consistent with the needs of Malay tourists who are generally categorised as risk-adverse, non-adventurous, traditional sightseeing tourists. Such characteristics are attributed primarily to the cultural dimensions of collectivism and high uncertainty avoidance. Even activities which require special skills are presented in a novice-friendly manner. For example, the skiing activity is introduced by the caption 'You don't need to know how to ski to have fun in Victoria's snowfields'. The statement is complemented by an accompanying visual depicting a Muslim mother and her young daughter on one of Victoria's ski mountains. The message conveyed by the visual is that Victoria's High Country and Snowfields is a family-friendly destination with family-friendly and novice-friendly activities. The visual and caption is further elaborated in the body copy which points out that ski lessons are available for 'all levels'.

The cross-cultural inputs by the Commissioners in this aspect were further enhanced in my Malay translation by ensuring that all skill-requiring activities are dealt with adequately. Although 'skiing' was presented in a culturally appropriate manner in the dedicated section on snowfields, it was perhaps overlooked in one of the most important parts of the brochure: its introductory page. The copy in the introductory section includes an action-filled imperative sentence 'Ski in the snowfields'. Given the cultural background of the Malay tourist, I toned down this sentence to 'Rasai keseronokan bermain salji' (Feel the enjoyment of playing with snow). In order to align with the convention of Malay politeness and indirectness, I avoided following the structure of the source text. 'Ski in the snowfields' was not simply translated as 'play with snow' but as 'feel the enjoyment of playing with snow'. The imperative verb 'ski' denoting physical action and energy consumption was replaced with 'rasai keseronokan' (feel the enjoyment) which implies a mental action with positive associations. I felt that it was necessary to implement this change given the fact that it is a highly promotional introductory section. In Malay, 'playing with snow' sounds more attractive aesthetically and poetically than other translation options such as 'learn how to ski'. Moreover, playing with snow is high on the wish-list of the Malay tourist, not to mention that the 'learning to ski' theme is presented later on in the brochure. In another example found in the caption of the first page of the brochure (Example 5), the alliterative phrase 'snow and surf' was used as a tool of emphasis to introduce the destination as the ideal holiday destination:

EXAMPLE 5

\begin{tabular}{|c|c|c|}
\hline Source Text (ST) & $\begin{array}{c}\text { Cultural-Conceptual } \\
\text { Translation (CCT) }\end{array}$ & $\begin{array}{c}\text { Back-Translation } \\
\text { (BT) }\end{array}$ \\
\hline $\begin{array}{l}\text { From snow and } \\
\text { surf, Victoria is the } \\
\text { ultimate adventure } \\
\text { playground for } \\
\text { families and } \\
\text { romantics }\end{array}$ & $\begin{array}{l}\text { Dari kedinginan salji ke } \\
\text { keindahan pantai, Victoria } \\
\text { adalah destinasi yang } \\
\text { terunggul untuk percutian } \\
\text { keluarga dan pasangan } \\
\text { romantik }\end{array}$ & $\begin{array}{l}\text { From the coolness of } \\
\text { snow to the beauty of } \\
\text { the beach, Victoria is the } \\
\text { ultimate destination for } \\
\text { family and romantic } \\
\text { couple holidays }\end{array}$ \\
\hline
\end{tabular}

There is still a problem with the word 'surf' as it is a skillrequiring activity. This required me to 'tame' the sentence while at the same time trying to preserve the poetic force. In doing this, I replaced 'surf' with another seascape theme to which the Malay tourist can relate more effectively: the beauty of the beach. I also managed to recreate a poetic force of alliteration, assonance and consonance in the Malay translation by adding two parallel words: 'kedinginan' (coolness) and 'keindahan' (beauty). The phrase 'adventure playground' is also toned down to 'holiday destination'. Although the concept of 'adventure playground' (Brett, Moore, \& Provenzo, 1993, p. 26) in English does not imply the true sense of risk and uncertainty but rather 'safe risks', it highlights the contrast between safe and risky, adventure and comfort, and emulates the contrast between the notion of 'playing with snow' and 'surfing rolling waves'. And since the adventure-oriented notion of 'surf' has been replaced by the sightseeing-oriented notion of 'beach', shifting from 'adventure playground' to 'holiday destination' would be perfectly appropriate for purposes of consistency. Further, in keeping within the framework of sightseeing, adventureperformance oriented experiences were translated as sightseeing-oriented experiences in the Malay copy such as in Example 6:

EXAMPLE 6

\begin{tabular}{lll}
\multicolumn{1}{c}{ Source Text (ST) } & $\begin{array}{c}\text { Cultural-Conceptual } \\
\text { Translation }(\text { CCT) }\end{array}$ & Back-Translation (BT) \\
\hline $\begin{array}{l}\text { [T]ake a drive on the } \\
\text { world's most scenic } \\
\text { road }[\ldots]\end{array}$ & $\begin{array}{l}\text { Nikmati panorama } \\
\text { terindah di dunia }\end{array}$ & $\begin{array}{l}\text { Enjoy the most beautiful } \\
\text { panorama in the world }\end{array}$ \\
\hline
\end{tabular}

This is done by shifting the focus from the adventure of driving to the beauty of nature and scenery, from the reader to the destination, and from active performance to passive gazing. 
On the notion of the beauty of nature, I also ensured that the concept of 'untamed nature' was replaced by the concept of 'tamed nature'. This is because, while the notion of beauty in Anglophone culture might include both 'tamed' and 'untamed' nature, in Malay culture, beauty is often associated only with 'tamed nature'. For Malays, an appealing image of nature is that which is benevolent, caring and harmonious (Sulaiman, 2013, p. 157). For example, to avoid the negative connotations associated with 'cliffs' in Malay, it was chunkedup to 'bentuk muka bumi' (terrains). The meaning lost in the 'chunking up' process is regained through the accompanying visuals which provide a clear idea of the exact notion of terrain in question. Meanwhile, the adjective 'rugged' is not translated literally to 'berceranggah' as the latter does not evoke any sense of beauty in the Malay mind. A literal translation of 'rugged cliffs' (cenuram berceranggah) would sound like a 'technical' term used in a geography book. Far from sounding 'promotional', they evoke notions of risk, danger, and wilderness. In order to recreate the intended function of the source text, that is, to represent beauty, the adjective 'rugged' is 'unpacked' and 'reduced' to its functional purpose of creating an appealing destination image in the mind of the target text reader. This is achieved by opting for an explicit positive keyword, that is, 'mengagumkan' (fascinating) in the target text (Example 7).

EXAMPLE 7

\begin{tabular}{|c|c|c|}
\hline Source Text (ST) & $\begin{array}{c}\text { Cultural-Conceptual } \\
\text { Translation (CCT) }\end{array}$ & $\begin{array}{c}\text { Back-Translation } \\
\text { (BT) }\end{array}$ \\
\hline $\begin{array}{l}\text { In addition to a } \\
\text { shoreline embellished } \\
\text { with beautiful beaches } \\
\text { and rugged cliffs, the } \\
\text { region also boasts } \\
\text { enclaves of protected } \\
\text { bushland and colourful } \\
\text { coastal villages. }\end{array}$ & $\begin{array}{l}\text { Di samping jaluran } \\
\text { pantai dan bentuk muka } \\
\text { bumi yang } \\
\text { mengagumkan, kawasan } \\
\text { ini kaya dengan } \\
\text { khazanah flora dan } \\
\text { fauna dan } \\
\text { perkampungan persisir } \\
\text { pantai yang indah. }\end{array}$ & $\begin{array}{l}\text { In addition to } \\
\text { fascinating beaches and } \\
\text { terrains, this region is } \\
\text { rich with flora and fauna } \\
\text { treasures and beautiful } \\
\text { coastal villages. }\end{array}$ \\
\hline
\end{tabular}

Similarly, 'bushland' was not translated to its literal dictionary equivalent 'hutan belukar' which does not evoke positive associations in the Malay culture. The phrase 'hutan belukar' evokes the image of 'untidy', rough, and harsh naturescapes. Instead it is chunked-up to what would be perceived as highly positive: 'khazanah flora dan fauna' (flora and fauna treasures).

At the stylistic level, the English source text was generally structured within the 'sightseeing' framework, exhibiting discursive features analogous to those that exist in Malay tourism promotional discourse. These stylistic features create an ambiance of comfort, convenience and relaxation rather than energy, action, and dynamism. A key stylistic feature is indeed the scarce use of the imperative voice and the dominance of the expository mode over the instructional mode. Furthermore, the discourse of the source text is styled in such a way that it focuses on the tourist attractions rather than tourist performance. Emphasis is placed on how the destination can perform for the tourist instead of how the tourist can perform at the destination. The fact that the stylistic features of the source text correspond to those exhibited by comparable TPMs in Malay, facilitates the translation process to a great extent. This meant that many parts of the source text did not require major restructuring at the linguistic level.

Some of the stylistic changes carried out to enhance the functionality of the target text included mitigating some imperative structures in line with the convention of Malay politeness by using modal verbs such as 'boleh' (can, may) (Example 8):

EXAMPLE 8

\begin{tabular}{|c|c|c|}
\hline Source Text (ST) & $\begin{array}{c}\text { Cultural-Conceptual } \\
\text { Translation (CCT) }\end{array}$ & $\begin{array}{c}\text { Back-Translation } \\
\text { (BT) }\end{array}$ \\
\hline $\begin{array}{l}\text { Head to the Spring } \\
\text { Street end of Collins } \\
\text { Street for luxury brands } \\
{[\ldots]}\end{array}$ & $\begin{array}{l}\text { Anda boleh ke Collins } \\
\text { Street untuk barangan } \\
\text { jenama mewah }[\ldots]\end{array}$ & $\begin{array}{l}\text { You can go to Collins } \\
\text { Street for luxury brand } \\
\text { goods }[\ldots]\end{array}$ \\
\hline
\end{tabular}

Imperative verbs denoting physical actions were also mitigated by replacing physical action imperative verbs with non-physical action imperative verbs. For example, the imperative verbs 'ski' and 'pan' were replaced by the imperative verb 'rasai' (feel), and 'sertai' (take part) respectively (Example 9):

EXAMPLE 9

\begin{tabular}{lll}
\multicolumn{1}{c}{ Source Text (ST) } & \multicolumn{1}{c}{$\begin{array}{c}\text { Cultural-Conceptual } \\
\text { Translation }(\text { CCT) }\end{array}$} & \multicolumn{1}{c}{$\begin{array}{c}\text { Back-Translation } \\
\text { (BT) }\end{array}$} \\
\hline $\begin{array}{l}\text { Ski in the snowfields; } \\
\text { pan for gold in the } \\
\text { goldfields }[\ldots]\end{array}$ & $\begin{array}{l}\text { Rasai keseronokan } \\
\text { bermain salji, sertai } \\
\text { aktiviti mendulang emas } \\
{[\ldots]}\end{array}$ & $\begin{array}{l}\text { Feel the joy of playing } \\
\text { with snow, take part } \\
\text { in the panning for gold } \\
\text { activity }[\ldots]\end{array}$ \\
& & \\
\hline
\end{tabular}

Emphasis in ST mine.

Apart from the imperative voice, other expressions which carry a sense of compulsion were translated into expressions which carry a sense of option. In Example 10, for example, 'should try' is translated as 'boleh mencuba' (can try):

EXAMPLE 10

\begin{tabular}{lll}
\multicolumn{1}{c}{ Source Text $(\mathbf{S T})$} & $\begin{array}{c}\text { Cultural-Conceptual } \\
\text { Translation }(\mathrm{CCT})\end{array}$ & \multicolumn{1}{c}{$\begin{array}{c}\text { Back-Translation } \\
\text { (BT) }\end{array}$} \\
\hline $\begin{array}{l}\text { Thrill seekers should } \\
\text { try The Edge } \\
\text { experience }\end{array}$ & $\begin{array}{l}\text { Bagi yang inginkan } \\
\text { cabaran, mereka boleh } \\
\text { mencuba pengalaman } \\
\text { The Edge. }\end{array}$ & $\begin{array}{l}\text { For those who want } \\
\text { challenges, they can } \\
\text { try The Edge } \\
\text { experience. }\end{array}$ \\
& &
\end{tabular}

Emphasis in ST mine.

Furthermore, as exemplified in some of the previous examples (Example 4, Example 5) the persuasive effect created by poetic devices in the source text is reproduced as much as possible in the target text through the use of Malay poetic devices. In fact, where the function of form precedes that of content, priority is given to recreating these stylistic effects even at the expense of the semantic value of the text. The following example is a highly persuasive caption promoting Victoria's Goldfields and Spa Country (Example 11): 
EXAMPLE 11

\begin{tabular}{|c|c|c|}
\hline Source Text (ST) & $\begin{array}{c}\text { Cultural-Conceptual } \\
\text { Translation (CCT) }\end{array}$ & $\begin{array}{c}\text { Back-Translation } \\
\text { (BT) }\end{array}$ \\
\hline $\begin{array}{l}\text { Leave relaxed and a } \\
\text { little richer after a visit } \\
\text { to Victoria's goldfields } \\
\text { and spa country }\end{array}$ & $\begin{array}{l}\text { Selami zaman silam dan } \\
\text { rasai nikmat kesegaran } \\
\text { dengan mengunjungi } \\
\text { perkampungan lombong } \\
\text { emas dan kawasan spa } \\
\text { Victoria }\end{array}$ & $\begin{array}{l}\text { Experience the past } \\
\text { and feel the delight of } \\
\text { freshness by visiting } \\
\text { Victoria's gold mine } \\
\text { village and spa region. }\end{array}$ \\
\hline
\end{tabular}

Emphasis in ST mine.

The double-alliteration phrase 'leave relaxed and a little richer' is translated into Malay with two priorities in mind: (a) recreating a poetic effect to arrest the reader's attention; (b) employing distinctive idiomatic phrases to enhance the poetic effect. This is achieved by dropping the 'riches' theme from the text and compensating it with another prominent theme of the destination, that is, 'the past'. 'Leave relaxed' is translated as 'rasai nikmat kesegaran' (feel the delight of freshness). This solution exploits the denotative meaning of 'kesegaran': from the root word 'segar' in Malay it signifies rejuvenation, and invigoration, as well as freshness. The second part - '[leave] a little richer' - is translated as 'selami zaman silam' (experience the past) - a poetic phrase which combines alliteration, consonance and assonance. It should be noted that in the source text, 'leave relaxed' corresponds to 'spa country' while 'a little richer' corresponds to 'goldfields'. In terms of arrangement, the textual elements would tally better had they been arranged as follows: 'Leave a little richer and relaxed after a visit to Victoria's goldfields and spa country'. However, in the source text, coordination was neglected at the expense of creating a more forceful poetic effect. In the target text, the order of the two thematic phrases was reversed by moving the more forceful alliterative phrase 'selami zaman silam' to the forefront of the sentence. This in a way recoordinated the corresponding themes.

The persuasive effect of the target text was also induced by introducing authentic Malay expressions. The use of such unique expressions enhances the authenticity of the target text, hence promoting the relationship between the text and its target readership (reception) (Example 12).

EXAMPLE 12

\begin{tabular}{lll}
\hline \multicolumn{1}{c}{ Source Text (ST) } & $\begin{array}{l}\text { Cultural-Conceptual } \\
\text { Translation (CCT) }\end{array}$ & $\begin{array}{c}\text { Back-Translation } \\
\text { (BT) }\end{array}$ \\
\hline $\begin{array}{l}\text { From elegant Southbank } \\
\text { on the Yarra River, to } \\
\text { the city centre's eclectic } \\
\text { laneways [...] (p. 263) }\end{array}$ & $\begin{array}{l}\text { Dari kawasan elegen } \\
\text { Southbank di Yarra } \\
\text { River, ke lorong-lorong } \\
\text { beraneka ragam budaya } \\
\text { di pusat Bandar [...] }\end{array}$ & $\begin{array}{l}\text { From the elegant area } \\
\text { of Southbank on the } \\
\text { Yarra River, to the } \\
\text { laneways of cultural } \\
\text { varieties in the city } \\
\text { centre. }\end{array}$ \\
\hline $\begin{array}{l}\text { In October, Phillip } \\
\text { Island switches gear for } \\
\text { the 500cc Motorcycle }\end{array}$ & $\begin{array}{l}\text { Pada bulan October, } \\
\text { pulau ini bertukar } \\
\text { menjadi gelanggang }\end{array}$ & $\begin{array}{l}\text { In October, this island } \\
\text { transforms into a } \\
\text { [fighting] ring for the }\end{array}$ \\
$\begin{array}{lll}\text { kepada acara Grand Prix } \\
\text { motosikal 500cc. }\end{array}$ & $\begin{array}{l}\text { 500cc Motorcycle } \\
\text { Grand Prix event. }\end{array}$ \\
\hline $\begin{array}{l}\text { [T]housands of Little } \\
\text { Penguins, unique to this } \\
\text { part of the world, } \\
\text { waddle up the beach to } \\
\text { the delight of visitors. } \\
\text { (p. 268) }\end{array}$ & $\begin{array}{l}\text { [R]ibuan burung penguin } \\
\text { kecil, terkedek-kedek } \\
\text { lenggang kangkung }\end{array}$ & $\begin{array}{l}\text { [T]housands of little } \\
\text { penguins waddle up } \\
\text { the beach in a }\end{array}$ \\
\hline
\end{tabular}

\begin{tabular}{lll}
\hline $\begin{array}{l}\text { [F]or a dinner with a } \\
\text { difference, try the } \\
\begin{array}{l}\text { Colonial Tramcar } \\
\text { Restaurant. (p. 263) }\end{array}\end{array}$ & $\begin{array}{l}\text { Bagi pengalaman makan } \\
\text { malam yang lain } \\
\text { daripada lain pula, } \\
\text { cubalah Restoran } \\
\text { Colonial Tramcar [...] }\end{array}$ & $\begin{array}{l}\text { [F]or a dinner } \\
\text { experience which is } \\
\text { different from others, } \\
\text { try the Colonial } \\
\text { Tramcar Restaurant. }\end{array}$ \\
\hline $\begin{array}{l}{[\ldots] \text { try to strike it rich }} \\
\text { by panning for your own } \\
\text { gold. (p. 272) }\end{array}$ & $\begin{array}{l}{[\ldots] \text { mencuba nasib }} \\
\text { dengan mendulang bijih } \\
\text { emas. }\end{array}$ & $\begin{array}{l}{[\ldots] \text { try your luck by }} \\
\text { panning for gold ore. }\end{array}$ \\
\hline Emphasis in ST mine. & & \\
\hline
\end{tabular}

\section{CONCLUSION}

On the whole, the application of the CCT model in this translation project has highlighted several points, including the importance of cross-cultural input in the translation process. Cross-cultural input could be commissioner-initiated (e.g., at the pre-translation stage of content design and translation brief) or translator-initiated (e.g., at the mid-translation stage). Translator-initiated input could also be solely at the discretion of the translator (e.g., in the case of minor changes) or through mutual negotiation between the translator and the commissioner (e.g., in the case of core content changes). The amount of commissioner-initiated input available and the amount of translator-initiated input required has a direct bearing on the fluency of the translation process, effort and time required to translate, and rate of pay. It is obvious that commissioner-initiated input, made available through market research, requires time, effort and money. Similarly, translator-initiated input would also require additional time, effort and therefore money. Hence it is quite reasonable to say that the rate of pay should depend on how much input has been supplied by the commissioner and how much is still required by the translator.

The project also highlighted that while the translator has more knowledge in the language and culture of the target audience than the commissioner and is therefore the expert on the language and culture of the target audience, the commissioner has more knowledge of the tourism product and experience being promoted and is therefore the expert on the subject matter being translated. This underscores the importance of mutual negotiation between the translator and the commissioner. The project also demonstrated that a costeffective and efficient way of translating TPMs for different markets is to design source texts based on cultural similarities. For example, markets of different linguistic background but similar cultural values could be targeted using a single culturally-designed source text. This is proven by the fact that the source text designed for the Arab-Gulf market was, to a large extent, culturally appropriate for the Malay market. In other words, for the purpose of designing source texts, markets could be grouped together based on their cultural values.

More importantly, the application of the CCT model in the translation project gave the Commissioners a different perspective of the concept of translation. Both the approach and the outcome were very well received by the Commissioners, who recognized that an ideal scenario would be one in which they could find an accomplished translator who can implement the necessary culturally-driven changes. This project confirms the validity of CCT as an effective model for the translation of not only TPMs but promotional materials in general. It is also further proof that translator- 
commissioner relationship is an indispensable part of the professional translation process and that an effective translated TPM is contingent, to a large extent, on a successful negotiation between the translator and the commissioner. Last but not least, the project underlines the need for professional translators to be proactive in creating awareness among commissioners regarding the process of translation which is not only a transactional activity of direct language transfer but a process underpinned by 'deep' understanding of both cultures, hence the cultural mediator role for translators.

\section{Funding}

This work was supported by Universiti Kebangsaan Malaysia under Grant number GGPM-2016-023.

\section{References}

Brett, A., Moore, R. C., \& Provenzo, E. F. (1993). The complete playground book. New York: Syracuse University Press.

Federici, E. (2007). What to do and not to do when translating tourist brochures. In P. O. \& C. de Stasio (Eds.), The languages of tourism: Turismo e mediazione (pp. 99112). Milano: Unicopli.

Hall, E. (1976). Beyond culture. New York: Doubleday.

Hall, E. (1984). The dance of life. New York: Doubleday.

Hofstede, G., Hofstede, G. J., \& Minkov, M. (2010). Cultures and organizations: Software of the mind. New York: McGraw-Hill.

Katan, D. (2012). Translating the tourist gaze: From heritage and 'culture' to actual encounter. Pasos: Revista de Turismo y Patrimonio Cultural, 10(4), 83-95.

Kozak, M., Bigne, E., Gonzalez, A. N. A., \& Andreu, L. (2003). Cross-cultural behavior research in tourism:
A case study on destination image. Tourism Analysis, 8(2), 253-257.

MacKay, K. J., \& Fesenmaier, D. R. (2000). An exploration of cross-cultural destination image assessment. Journal of Travel Research, 38(4), 417-423.

Parks, T. (2014). Translating Style: A literary approach to translation - A translation approach to literature (2nd ed.). London: Routledge.

Pierini, P. (2007). Quality in web translation: An investigation into UK and Italian tourism web sites. The Journal of Specialised Translation, 8(July), 85-103.

Rajesh, R. (2013). Impact of tourist perceptions, destination image and tourist satisfaction on destination loyalty: A conceptual model. PASOS. Revista de Turismo y Patrimonio Cultural, 11(3), 67-78.

Sulaiman, M. Z. (2013). Translating tourism: A cultural journey across conceptual spaces. (PhD), Monash University, Melbourne.

Sulaiman, M. Z. (2016a). The misunderstood concept of translation in tourism promotion. The International Journal for Translation \& Interpreting Research, 8(1), 53-68.

Sulaiman, M. Z. (2016b). Translating Australian urban gastronamic experiences for Malay tourists. Pertanika Journal of Social Sciences \& Humanities, 24(S), 21-36.

Sulaiman, M. Z., \& Wilson, R. (2018). Translating tourism promotional materials: a cultural-conceptual model. Perspectives, 1-17. doi: 10.1080/0907676X.2018.1437193

Sumberg, C. (2004). Brand leadership at stake: Selling France to British tourists. The Translator, 10(2), 329-353.

Valdeón, R. A. (2009). Info-promotional material discourse and its translation: The case of the Asturian tourist board texts. Across Languages and Cultures, 10(1), 21-47. 